\title{
Environmental health issues in the wake of a major earthquake in West Sumatra, Indonesia
}

\author{
D. Fanany \\ School of Public Health, La Trobe University, Melbourne, Australia
}

\begin{abstract}
The 2009 earthquake in Padang, the capital city of the province of West Sumatra in Indonesia, devastated the city's physical landscape, causing material and economic damage that has yet to be repaired. Environmental health issues arising from the earthquake also remain mostly unresolved. Many of the earthquake's most devastating effects were exacerbated by the lack of effective contingency planning and responses in place. This paper presents the events relating to reconstruction efforts in the year following the earthquake and the environmental health issues that emerged, including problems related to the water supply and a serious outbreak of dengue fever. Four features of the Indonesian political landscape that affected the response to the disaster and the reconstruction process are identified: corruption; regional autonomy; technological leapfrogging; and the concept of pembangunan [development].

Keywords: West Sumatra, earthquake, environmental health, reconstruction.
\end{abstract}

\section{Introduction}

On September 30, 2009, an earthquake measuring 7.6 on the Richter scale struck the Indonesian province of West Sumatra. The earthquake's epicenter was in the region of Pariaman, on the coast just north of the provincial capital of Padang. While earthquakes are not uncommon either in Indonesia as a whole or in West Sumatra specifically, it had been relatively unusual for the epicenter to be in such close proximity to a major city. As such, little attention had been given to earthquake-resistant construction or city planning, and authorities had little in the way of contingency preparation for such an event. Official records reported 1,115 deaths and nearly 3,000 serious injuries as a result of the quake [1]. The city of Padang suffered severe and extensive damage, with many buildings either 
destroyed outright or damaged so badly they needed to be demolished, and damage to gas and electricity lines that resulted in fires.

\section{Post-disaster reconstruction}

Severe disruption to the city's daily routine and operations followed the earthquake. According to the Departemen Sosial [Department of Social Affairs], many government and commercial buildings either sustained major damage or were entirely leveled, notably the Dinas Kelautan Perikanan Provinsi Sumatera Barat [Provincial Office of Maritime Affairs]; several shops and office buildings in the Sawahan neighborhood; several hotels including Hotel Ambacang, Hotel Ina Muara, and Bumi Minang; major shopping centers such as Plaza Andalas and Matahari; the state courthouse in Siteba; and the Muhammadiyah mosque in Simpang Haru [2]. The central offices of many banks that were located in the main market area were severely damaged, including Bank Indonesia (BI), the Padang branch of the nation's central bank [3]. Not only did this require the setup of emergency procedures to meet the public's pressing need for cash, BI was unable to conduct any government business, a major problem considering the number of people employed by the government (health care personnel, police and military officers, public school teachers, employees of government offices, and others). In the older Pondok neighborhood, many businesses' premises collapsed outright, trapping employees in the rubble [4].

Schools were particularly hard hit by the earthquake -1078 were reported damaged in the disaster. Despite the existence of funds for this aspect of the reconstruction coming from Dana Alokasi Khusus Bencana [Special Allocation of Funds for Disaster] which are released as part of the national and regional budgets, the national newspaper Republika [5] reported that only 402 schools had been rebuilt or repaired one year after the disaster. The local government is hoping for more international aid to speed the reconstruction.

In the wake of the earthquake, the government has put a number of contingency plans and responses into place. For example, in September 2010, construction began on an earthquake "escape building" behind the governor's office. The escape building is intended to provide shelter for both provincial-level officials and members of the public in the event of another earthquake and was constructed with the assistance of Japanese experts [6]. The Andalas Bridge was also designated a tsunami evacuation route, with upgrades planned. The local government encountered a number of problems with this, most notably difficulties in reaching an agreement with residents to purchase land required for the upgrade [7]. This has been particularly vexing to local authorities, considering the periodic panics and fear of tsunamis and earthquakes apparent among the public.

Approaching two years after the earthquake, reconstruction efforts have proceeded slowly and remain far from complete. Many buildings have not been rebuilt, including large parts of the main market, and many restaurants and smaller stores have closed permanently. Much of the rubble resulting from the quake has not been cleared, and a large number of lots remain abandoned especially in older parts of the city. Both of these last two observations present 
clear environmental health hazards, as they serve to multiply the number of potential breeding places for mosquitoes and other vectors.

\section{Public services}

The immediate aftermath of the earthquake saw Padang's public services reduced to nearly zero. There was no electricity at all in the city, although other population centers farther from the epicenter such as Bukittinggi, Solok, and Payakumbuh were relatively unaffected [8]. Electricity was restored to much of the city relatively quickly - about $85 \%$ of Padang was back on the grid within five days. The reconstruction effort aimed to fully restore electricity within 10 days of the earthquake, and the National Electric Company [Perusahaan Listrik Negara $=$ PLN] sent 450 extra technicians from North Sumatra, Riau, Jambi, Bengkulu, Palembang, Lampung, Jakarta, and Bandung to work on this [9].

Communications were, overall, not impacted as much as might be expected given the severity of the earthquake. This was largely due to the popularity and ubiquity of mobile phones among the residents of Padang; while landlines were entirely disabled by the earthquake, some mobile users did not lose service at all [10]. In the aftermath, PT Excelcomindo Pratama Tbk was providing free mobile phone and wi-fi service in Padang. Their network was mostly undamaged, and they brought in generators to maintain services in the worst affected areas [11]. The fuel supply was also restored very quickly, with 22 gas stations in Padang, eight in Pariaman, and seven in Gunung Kerinci back in service by October 8, 2009 [9]. Additional fuel was brought by truck from Dumai, Siak, Sibolga, and Jambi, all located in neighboring provinces, which helped prevent severe shortages.

By contrast, the disruption to the city's water supply was extensive and longlasting. Damage to installations belonging to PDAM Padang [Perusahaan Daerah Air Minum Padang = Padang Regional Drinking Water Company] ,the city's water company, was estimated at 45 billion rupiah resulting from destruction of water mains and reticulation systems, including underground piping originally installed during the Dutch era which was very difficult to access [12]. By the end of October 2009, most of the water plants were fully operational, but much of the reticulation system had to be replaced, and some parts of the city were being supplied by tanker truck. The director of PDAM Padang, Azhar Latif, predicted that it would take six months to fully restore water to the city [13]. Despite this issue being no less a priority than any other and the government's seeking assistance both within Indonesia and from outside the nation (such as the donation of water purifiers from two Dutch companies as reported by Radio Nederland Wereldomroep [14]), little progress was made in restoring service in the following weeks and, indeed, years. Radio Republik Indonesia [15] reported that many residents of Padang still had inadequate city water, with some locations having none at all during the day and a very limited supply at night. Many residents have attempted to adapt by buying tanks to collect rainwater [16], while anecdotal evidence suggests extremely high levels of dissatisfaction but also resignation to the situation. 


\section{Dengue fever}

Dengue became a pressing issue in the aftermath of the earthquake, as the widespread destruction combined with heavy rainfall resulted in many new breeding sites for mosquitoes, while waste water disposal, water services, and toilet and bathing facilities broke down in many parts of the city leading to even more water present in the living environment. Despite warnings from authorities about environmental health risks and suggestions to the public that they take precautions and attempt to clean up their immediate environment, the number of cases of dengue reported in Padang rose dramatically in the days following the quake [17]. At the end of October 2009, the Indonesian Red Cross was planning to fog a number of neighborhoods where high numbers of cases had been reported. Some of these locations had reported more than a hundred new cases of dengue in a period of less than four weeks [18].

By early 2010, various estimates of the extent of the upsurge in cases of dengue were published. One regional hospital, RSUD Dr Rasidin, reported in February 2010 that most of the cases it had seen were in children and that the number had been increasing every month since the earthquake [19]. According to Republika [20], the official total number of cases in early 2010 was 1586, of whom 8 had died while 277 had been placed in intensive care. Because of widespread damage to Puskesmas [Pusat Kesehatan Masyarakat = public health centers] and general underreporting, the actual number of cases may be higher. Dengue and other fever diseases are endemic in Padang, and many people do not bother to go to doctors, feeling that little can be done. Those from higher SES levels tend to seek medical treatment for children suspected of having dengue, but adults may treat themselves until or unless their condition becomes critical.

It is worth noting that vector borne disease is a major issue in Padang and West Sumatra at all times, not just in the wake of natural disaster. There are periodic outbreaks and, at times, the media has reported epidemics. Nonetheless, most residents do not fully appreciate the connection between the presence of mosquito vectors and dengue and malaria. Many people view mosquitoes as a nuisance, which they ignore or attempt to kill by spraying bedrooms with Baygon (carbamate propoxur) or using combustible mosquito coils. All houses have multiple mosquito breeding sites inside or in the immediate vicinity as water for bathing and other uses is stored in open tubs filled occasionally from a tap. Ditches containing slow moving or stagnant water line all streets (there is no sewer system), and yards generally contain potted plants that may retain small amounts of water. The local authorities occasionally fog residential areas, but vector control tends to be sporadic and unsystematic.

\section{Public response}

In the wake of the earthquake, a great deal of public discussion was observed as residents attempted to understand the events they had witnessed. Some of this discussion was religious in nature, with particular focus on God's plans which cannot be comprehended by mortals and the need to accept the unchangeable 
will of God [21, 22]. Others focused on the scientific view of the event, attempting to explain the earthquake in terms of geology and offer a method for predicting similar future incidents.

However, even this scientific view of the disaster was formulated by the public and proved relatively resistant to input from actual experts or authorities on geology. Reflecting Padang's increasing connection to global culture and internet sources (at least partially made possible by extensive mobile phone use), these interpretations clearly drew on existing trends and tropes in pseudoscience and scientifically questionable material available on the internet. An excellent example of this is the events surrounding a halo around the sun observed in October 2010, which was widely interpreted as a natural sign of an impending earthquake and tsunami, albeit one without a clearly-defined link or mechanism of causation. Although this phenomenon was easily explainable, likely being the result of the presence of reflective particles in the air after the eruption of Mount Merapi near Yogyakarta, fear of another disaster spread rapidly by word of mouth, leading to large numbers of people leaving work and school and avoiding public places [23].

Some of the discussion of the earthquake took on an almost conspiratorial tone. For example, another story circulated that Fauzi Bahar, the mayor of Padang, had been warned by a panel of Japanese geologists that a cataclysmic earthquake would occur around November 25, 2010. Supposedly, this earthquake would break the island of Sumatra in half, creating a new body of water, in an event similar to the Black Sea deluge theory which is widely available online [24]. This theory suggests that the level of the Black Sea rose abruptly and catastrophically around $5600 \mathrm{BC}$ due to the level of the Mediterranean Sea rising, which caused large amounts of water to pour over a sill in the Bosporus, leading to dramatic landscape changes on the Black Sea's shores and devastation to communities in the region. It is now generally accepted that the basic scenario probably did occur, but both the extremity and suddenness in the rise of the Black Sea's level is disputed, with some experts suggesting that smaller flows of water may have moved in both directions over a period of centuries. There are many references to the Black Sea deluge theory in pseudoscientific sites on the internet, claiming it as a historical event that inspired myths of a great flood, as in the stories of Noah, Gilgamesh, or Deukalion. Fears of the supposed November $25^{\text {th }}$ earthquake were amplified and perpetuated by viral media, including anonymous text messages which contained details of the impending disaster, said to be coming on "the date of the full moon when the earth's gravitational field with the moon is aligned with the planet Venus" [25]. This story had a profound impact on the public's mood in Padang, with many people reluctant to travel far from their homes or visit public places like the main marketplace, despite other news sources reporting that the mayor never in fact met with any such experts and was never told anything of this type [26, 27]. 


\section{Discussion}

There are four interrelated phenomena that significantly affected the response to the earthquake that occurred in Padang, West Sumatra on September 30, 2009, and that are significant in understanding Indonesian society in general. They are corruption; regional autonomy; technological leapfrogging; and the Indonesian concept of pembangunan [development] that became a central feature of planning and policy during the New Order and still features prominently in the government's approach to facilities and services provision.

Corruption, which has been a hot-button issue in Indonesia since the end of the New Order government in 1997, was blamed for both exacerbating the effects of the earthquake and hindering the reconstruction effort. Accusations of corruption in the distribution of aid, both from the government and from other sources, also emerged very quickly and even became the subject of an investigation at the national level [28]. The level of destruction also led to speculation that serious corruption was involved in the construction of schools and public buildings. West Sumatra's then-governor, Gamawan Fauzi, commented that public buildings are supposed to be able to withstand quakes measuring 8 on the Richter scale [29]. However, enforcement of this type of regulation has historically been lax. Additionally, the director of PDAM Padang is on trial for the alleged corruption of 2.5 billion rupiah from the company's funds during the period from 2005 to 2009 [30], the implication being that these funds should have been used to upgrade the water system in the city.

It was hoped that Regional Autonomy would lessen the incidence of corruption and that the resulting decentralization would allow for greater transparency and public involvement in government. While it is perhaps the case that there it is more possible for members of the public to influence their local administration, corruption has, in fact, increased dramatically across Indonesia under Regional Autonomy. What seems to have occurred is a multiplication of existing patterns of misuse and personal enrichment throughout the lower levels of administration. In other words, it has been suggested that a decentralization of government authority has also led to a decentralization of corruption (see [31]). The main difference that has emerged during the period of Regional Autonomy is that the public is more sensitized to the issue of corruption such that the nation has seen a series of highly publicized prosecutions of public officials for abuse of power. One such example is the case of Azhar Latif of PDAM Padang mentioned above. The then governor of West Sumatra, Zainal Bakar, was similarly charged with corrupting 6.4 billion rupiah from the regional budget in 2002, as was a former governor of Aceh, Abdullah Puteh, who was accused of corrupting 30 billion rupiah [32].

Under the rubric of pembangunan [development] that became the catch cry of the New Order government, development efforts that would bring Indonesia up to the standard of the west were the main focus. One element of the five year development plans of the New Order was the electrification of much of the nation. The availability of power in rural areas, which in West Sumatra occurred during the late 1970s and early 1980s, changed the nature of people's experience, 
especially in that it allowed them to watch television and develop different patterns of work and employment. Electricity was difficult for individuals to develop on an individual basis because of the cost and difficulty of running generators such that this kind of development was not only welcomed but seen to be of enormous benefit. In this context, the contrast with the provision of water is marked. It is easy for improvements to water systems to receive less consideration, publicity, and attention, even from the government, compared to electricity. While water is no less critical to modern life and economic activity and to the successful functioning of a city, electricity is closely associated in the popular imagination with modernity and is the force behind many obvious symbols of progress such as television and the internet. Improvements to water systems require extensive planning and work that is often felt to be less "glamorous" than electrification; and the health and economic improvements bestowed by a functional water system may take years to be fully realized, while the results of a new or upgraded electrical grid can often be literally pointed to.

West Sumatra is a tropical region (the equator passes through the northern part of the province at the town of Bonjol) with very heavy rainfall. While there is a rainy season occurring from about October to February, there is no time of year when it does not rain. It is estimated that average rainfall is almost $400 \mathrm{~mm}$ per month with an average 17 days of rain per month [33]. Historically, the public has had ample access to water, albeit often of poor quality, and there are few parts of the province where water availability is a problem. Thus it has been relatively easy for the provincial government during the New Order and now for local governments under Regional Autonomy to overlook the need to upgrade aging water systems because the public has a historical capability to manage its own water. However, West Sumatra, like most of Indonesia, has experienced rapid urbanization and, especially for residents of Padang, is no longer a mostly rural society. As the earthquake demonstrated, a large number of people in cities and towns are now dependent on city water and do not have access to their own wells or sources of surface water as they did several decades ago when city living often resembled urban villages, rather than western-type housing complexes. Despite this, authorities have felt less pressure to repair the water system because many city residents still do have private wells or are prepared to collect rainwater. This willingness to provide their own water is probably partly historical but also an effect of the relative abundance of water for free.

The difference between the provision of electricity and water underscores the problem of technological leapfrogging in West Sumatra and Indonesia in general. National development efforts have often focused on the more visible aspects of technology, rather than those that are important but largely invisible to the public. The result has been a patchwork of innovation ranging from preindustrial conditions (no sewers and only open ditches for wastewater drainage) to the latest technology of the globalized mainstream (Blackberry service). The earthquake in Padang exposed several significant examples of this phenomenon. The most interesting of these is the situation regarding mobile phones and communication in general. For years, the popularity of mobile phones has been increasing in Padang, partly for the precise reason that landlines have been 
notably unreliable and very expensive. The advent of cheap prepaid phones and instantaneous recharge for small amounts has meant that almost everyone, regardless of SES, education or employment status, now has a phone and potential access to the internet. It has been estimated that some 30 million Indonesians use the internet regularly, often on mobile telephones, and most of this use seems to consist of social networking, surfing topics of interest, and email, rather than more serious academic or business purposes [34].

Mobile phone service is provided largely by private companies that have been licensed to operate since the end of the New Order. Prior to this, all telephone service was provided by Telkom Indonesia. At present, the national government is still the majority stockholder in PT Telekom, but it has diversified its services considerably in the last decade in order to compete with private providers, including in the cable TV market. According to PT Telekom itself, it currently has 8.4 million customers using landlines, 15.1 million using wireless telephones, 81.6 million mobile customers [35]. These statistics clearly illustrate the impact of technological leapfrogging in that much greater emphasis (and consumer demand) is placed on the more technologically advanced forms of communication, while more traditional elements of the system, such as telephone cable networks, remain surprisingly underdeveloped. This has been a major problem for offices and institutions in the context of computer use, even though most institutional users have now switched to wireless networking.

The proliferation of technology, largely through the private sector, accelerated greatly following the end of the New Order government. Prior to that, there was a much higher level of government involvement through Badan Usaha Milik Negara [government owned businesses $=$ BUMN], guaranteed monopolies for industries in which high ranking members of the national government or military had an interest, and strict limitation of the private sector [36]. These restrictions began to be eased in the 1990s, but the majority of private providers emerged after 2000 in the context of Regional Autonomy which gave local governments the power to manage many sectors that had been controlled by the central government (education, health, business) and also to make laws and regulations that reflected the local context.

It soon became apparent that experience was lacking in many regions to handle the wide range of services that were now the responsibility of the local government. For the three decades of the New Order, the highly centralized system drew the best educated and capable individuals to Jakarta where there were many more opportunities for career advancement. Local governments were seen as merely implementing orders from the top and were not viewed as milieus where talent was likely to have an outlet. Under Regional Autonomy, however, it was vital for regional governments to attract experienced individuals back to their regions or origin. This gave rise to the phenomenon often referred to in Indonesia as daerahisme [regionalism]. Daerahisme has led to preferential hiring of individuals who come from the region in question, often to the exclusion of others who are more qualified or experienced but who come from other areas. The basis for this practice seems to be the resurgence in ethnic identity that accompanied Regional Autonomy, perhaps as a response to the imposition of a 
national culture across the country by the New Order government that conflicted with traditional practices in many regions. It is also the case that the relatively low level of government at which Regional Autonomy was implemented means that many regions are quite homogenous, as their boundaries coincide with traditional divisions between linguistic/cultural groups. This heightened interest in ethnic identity has also been apparent in the election of local government officials in many regions where local laws have been used to institutionalize religious practices (syariah law) or local customs (see Erb et al. [37]). As a result, there has often been less attention paid to general issues of health and development that the public has come to expect will continue in the same way as before.

In hindsight, the ongoing devastation resulting from the 2009 earthquake seems almost inevitable. The political milieu in Padang makes implementing any type of environmental health or contingency planning extremely difficult. While some changes have been seen in these areas since the end of the New Order government, corruption and the culture of personal enrichment remain, and the political will to enact policies whose benefit is not immediate is still lacking. Combined with the lack of consistency in infrastructure, these problems greatly exacerbated the effects of the earthquake and the environmental health problems that arose from it. The 2009 earthquake in Padang was a perfect storm, a cautionary confluence of factors whose shadow will hang over the city, the province, and the nation for a long time to come.

\section{References}

[1] Antara (2009) "Number of Fatalities in West Sumatra Quake Now 1115," Antara News, October 14, 2009. http://www.antaranews.com/en/ news/1255472809/number-of-fatalities-in-w-sumatra-quake-now-1-115

[2] Kristanti, EY (2009a) "Daftar Gedung Bertingkat yang Rusak di Padang," VivaNews, October 1, 2009. http://us.nasional.vivanews.com/news/read/ 93650-daftar_gedung_bertingkat_yang_rusak_di_padang

[3] Detik Finance (2009) "Gedung Rusak Berat, Kanti BI Padang Beroperasi Terbatas," October 2, 2009. http://us.detikfinance.com/read/2009/10/02/ 140953/1213785/5/gedung-rusak-berat-kantor-bi-padang-beroperasiterbatas

[4] Tempo Interaktif (2009) "Akibat Gempa, Ratusan Warga Padang Terjebak di Gedung Bertingkat," 30 September 2009. http://www.tempointeraktif.com/hg/nusa/2009/09/30/brk,20090930200134,id.html

[5] Republika (2010) "Baru Sebagian Jumlah Sekolah Rusak Akibat Gempa Padang Direhabilitasi," September 29, 2010. http://www.republika.co.id/ berita/breaking-news/nusantara/10/09/28/136964-baru-sebagian-jumlahsekolah-rusak-akibat-gempa-padang-direhabilitasi

[6] Rinaldi, I (2010) "Padang Punya Gedung Tahan Gempa," Kompas, September 30, 2010. http://regional.kompas.com/read/2010/09/30/ 22432777/Padang.Punya.Gedung.Tahan.Gempa 
[7] PadangTV (2010) "Pelebaran Jembatan Andalas Terkendala Harga Ganti Rugi,” PadangTV, December 14, 2010. http://newspadangtv.blogspot.com/ 2010/12/pelebaran-jembatan-andalas-terkendala.html

[8] Wahyuni (2009) "Pemulihan Listrik di Padang Lebih dari Seminggu," Detik Finance, October 1, 2009. http://us.detikfinance.com/read/2009/ 10/01/192705/1213259/4/pemulihan-listrik-di-padang-lebih-dari-seminggu

[9] ESDMWatch (2009) "Gempa Padang: Listrik dan BBM Dijanjikan Normal 10 Oktober," October 8, 2009. http://esdmwatch.com/e1/index.php? option=com_content\&view=article\&id=4554:gempa-padang-listrik-danbbm-dijanjikan-normal-10-oktober\&catid $=57$ :ketenagalistrikan\&itemid $=73$

[10] Candra, A (2009) "Gempa Putuskan Jaringan Kabel Telpon di Padang," Kompas, September 30, 2009. http://regional.kompas.com/read/ 2009/09/30/19362659/Gempa.Putuskan.Jaringan.Telepon.Kabel.di.Padang

[11] Gandhi, GS (2009) "XL Sediakan Telepon Umum Gratis di Padang," Tempo Interaktif, October 7, 2009. http://www.tempointeraktif.com/ hg/bisnis/2009/10/07/brk,20091007-201282,id.html

[12] Matanews (2009) "Gempa, PDAM Padang Rugi Rp45 M," November 8, 2009. http://matanews.com/2009/11/08/gempa-pdam-padang-rugi-rp45-m/

[13] TVOne (2009) "Jaringan PDAM Padang Normal 6 Bulan Lagi," October 21, 2009. http://www.tvonenews.tv/www/berita/25975/ jaringan_pdam_padang_normal_6_bulan_lagi.html

[14] Radio Nederland Wereldomroep (2009) "Perusahaan Air Belanda Bantu Padang," October 12, 2009. http://www.rnw.nl/bahasa-indonesia/article/ perusahaan-air-belanda-bantu-padang-0

[15] Radio Republik Indonesia (2011) "Pasca Gempa 2009, Debit Air PDAM Kota Padang Minim," February 8, 2011. http://www.rri.co.id/index.php? option=com_content\&view=article\&id=2204:pasca-gempa-2009-debit-airpdam-kota-padang-minim\&catid $=44$ :index-berita-terbaru

[16] Tempo Interaktif (2009b) "PDAM Rusak, Korban Gempa Padang Tampung Air Hujan," October 1, 2009. http://www.tempointeraktif.com/ hg/nusa/2009/10/01/brk,20091001-200214,id.html

[17] Kompas (2010a) "Penderita Pascagempa Padang Melonjak, February 24, 2010. http://nasional.kompas.com/read/2010/02/24/03483759/ Penderita.Pascagempa.Padang.Melonjak

[18] PMI (2009) "Fogging Untuk Lima Wilayah Endemik DBD di Kota Padang," October 27, 2009. http://pmicabangpadang.blogspot.com/2009/ 10/fogging-untuk-lima-wilayah-endemik-dbd.html

[19] Kompas (2010) "Penderita Pascagempa Padang Melonjak, February 24, 2010. http://nasional.kompas.com/read/2010/02/24/ 03483759/Penderita.Pascagempa.Padang.Melonjak

[20] Republika (2010) "Daerah Waspadai Wabah Demam Berdarah," February 8, 2010. http:bataviase.co.id/node/87482

[21] Antara (2009) "Warga Padang Sebagian Mulai Mengungsi Akibat Gempa," Antara, October 26, 2009. http://id.news.yahoo.com/antr/20101026/tplwarga-padang-sebagian-mulai-mengungs-cc08abe.html 
[22] Metro TV News (2009) "60 Siswa terjebak di BimBel GAMA," October 2, 2009. http://www.youtube.com/watch?v=QbOh0E4RVM4

[23] Malau, ILF (2010) "Muncul Cincin Matahari Warga Padang Mengungsi," Viva News, October 21, 2010. http://nasional.vivanews.com/news/ read/184159-halo-matahari-warga-padang-pilih-mengungsi

[24] Yanko-Hombach, V et al (2007) "Controversy Over the Great Flood Hypotheses in the Black Sea in Light of Geological, Paleontological, and Archaeological Evidence,” Quaternary International, 167-168: 91-113.

[25] Fanany, R "Local and Cultural Response to Major Earthquake in Padang, West Sumatra," paper presented at 'Living on the Edge,'the Fourth International Conference of the ISSRNC, University of Western Australia, Perth, December 16-19, 2010.

[26] Harian Singgalang (2010) "Warga Ditakut-takuti dengan SMS," November 15, 2010. http://www.hariansinggalang.co.id/sgl.php?module= detailberita\&id $=1867$

[27] Padang Today (2010) "Isu Gempa Semakin Menggelisahkan," November 25, 2010. http://www.padang-today.com/?today=news\&id=23286

[28] Kompas (2009) "Bantuan Korban Gempa Sumatera Barat Diselewengkan," October 30, 2009. http://infokorupsi.com/id/korupsi.php?ac=3837\&l= bantuan-korban-gempa-sumatera-barat-diselewengkan

[29] Kristianti, EY (2009) "Korupsi Perparah Dampak Gempa Padang?," VivaNews, October 6, 2009. http://us.nasional.vivanews.com/news/read/ 94821-korupsi_perparah_dampak_gempa_padang_

[30] Kompas (2010b) "Korupsi Dana representasi, Dirut PDAM Padang Diperiksa kejati Sumbar," December 16, 2010. http://infokorupsi.com/ $\mathrm{id} /$ korupsi.php?ac=8158\&l=korupsi-dana-representasi-dirut-pdam-padangdiperiksa-kejati-sumbar

[31] Tempo Interaktif (2004)"Desentralisasi Korupsi Melalui Otonomi Daerah," November 4, 2004. http://www.tempointeraktif.com/hg/narasi/2004/11/04/ nrs, 20041104-01,id.html

[32] Tempo Interaktif (2005) "Beringin dan Ka'abah di Dua Pengadilan," February 21, 2005. http://majalah.tempointeraktif.com/id/arsip/2005/02/21/ LU/mbm.20050221.LU105472.id.html

[33] Pemerintah Kota Padang (2009) Banyaknya Hari Hujan dan Curah Hujan di Kota Padang. http://www.padang.go.id/v2/content/view/3119/180/

[34] Internet World Stats, Telecommunications in Asia: Special Report, http://internetworldstats.com/stats3.htm\#asia

[35] Telkom Indonesia (2010) Profil Perusahaan. http://www.telkom.co.id/infoperusahaan/index.html\#telkom

[36] Tempo Interaktif (1998) "Monopoli, Stop di Sini," October 20, 1998. http://majalah.tempointeraktif.com/id/arsip/1998/10/20/HK/mbm.19981020 .HK96098.id.html

[37] Erb, M, Sulistiyanto, P and Faucher, C, eds Regionalism in Post-Suharto Indonesia, Routledge Curzon, London and New York, 2005. 